ACTA MYCOLOGICA

Vol. 41 (2): 299-304

2006
Dedicated to Professor Alina Skirgietto

on the occasion of her ninety fifth birthday

\title{
Tubakia dryina, symptoms and pathogenicity to Quercus robur
}

\author{
TADEUSZ KOWALSKI \\ Department of Forest Pathology, University of Agriculture \\ Al. 29 Listopada 46, PL 31425 Kraków \\ rltkowal@cyf kr.edu.pl
}

Kowalski T.: Tubakia dryina, symptoms and pathogenicity to Quercus robur. Acta Mycol. 41 (2): 299 304, 2006.

In 1999 disease symptoms on leaves of Quercus robur necrosis, deformation and blackening of leaf petiole, followed by premature leaf fall were observed. Tubakia dryina was isolated from necrotic tissues and its pathogenicity to oak proved in infection experiments. The fungus caused necrosis of shoots and leaves. Dying leaves displayed also blackening of leaf petiole.

Key words: Quercus, Tubakia dryina, pathogenicity, disease symptoms

\section{INTRODUCTION}

Infection of Quercus robur L. leaves by several fungi results in easily recognizable disease symptoms. Microsphaera alphitoides Griff. et Maubl. causes white powdery mildew on leaf surface (Mańk a 2005), Taphrina caerulescens (Desm. et Mont.) Tul. - discoloured spots, raised above and conclave below the blade (Ellis, Ellis 1985). Apiognomonia quercina (Kleb.) Hoehn. is causative agent of anthracnose, with blade necroses developed along veins (Nelly, Himelick 1967).

There are, however, numerous diseases causing spots on leaves. Their causing agents are difficult to identify due to lack of etiological symptoms, as it is in the case of Septoria quercicola (Desm.) Sacc., Cryptocline cinerescens (Bubak) Arx or Mycosphaerella spp. (Gilman, Wadley 1952; But in 1996). Some symptoms, in particular, are not specific as they occur on leaves previously damaged by gall-making insects (Butin 1992).

Various symptoms of unknown etiology are common on oak leaves. The conditions favouring their occurrence are not known yet (Butin 1996; Kowalski, Durak 2000). A few years ago not specific symptoms of this kind were observed on $Q$. robur leaves, leading to premature defoliation in spring. The symptoms are characterized in the work and results of investigation on the disease etiology are presented. 


\section{MATERIALS AND METHODS}

Leaves of Q. robur with disease symptoms were collected in June 1999 near Opole (south-west Poland). The symptoms were described in detail and isolations of fungi from necrotic tissues were performed. Leaf disinfection followed the method used for beech leaves by Sieber and Hugentobler (1987). Leaf bases with petioles were dipped in $96 \%$ ethanol $(1 \mathrm{~min})$, then in sodium hypochlorite containing ca $4 \%$ of active chlorine ( $3 \mathrm{~min}$ ) and again in $96 \%$ ethanol $(0.5 \mathrm{~min})$. After drying in sterile filter paper, from leaf petioles with symptoms 3-mm-long inocula were taken and placed onto 2\% malt extract agar (MEA, Difco) in Petri dishes. Incubation for 4 weeks was performed in dark, at room temperature.

The isolation from necrotic tissues yielded almost exclusively Tubakia dryina. Four cultures of the species were grown on MEA and potato dextrose agar (PDA, Difco) at $20^{\circ} \mathrm{C}$, to describe their morphology and to examine and measure their conidiospores (macro- and microconidia).

Infection experiment on leaves was performed on $Q$. robur trees (ca 10-year-old) in the vicinity of the Ojców National Park of Nature. Isolate No. HMIPC 16617 was used for inoculation. Developing oak leaves (n 20) were covered on May 2, 2005, and May 19, 2005, with spore suspension (ca $10^{2}$ viable conidia per ml) obtained from 6-8-week-old cultures grown on MEA. Besides, at the same time, young shoots ( $\mathrm{n}$ 6) were wounded with sterile lancet. In the wounds (3-mm-long) going along the shoot an inoculum of ca $5 \mathrm{~mm}^{2}$ of MEA grown with $T$. dryina mycelium was placed and the shoot covered with parafilm. Control consisted of wounded shoots with sterile medium. Four and eight weeks after inoculation the disease symptoms were evaluated and the fungi isolated from 210 fragments of necrotic leaf tissue, leaf petioles and shoots, as described above.

\section{RESULTS}

The disease symptoms on $Q$. robur leaves observed in 1999 near Opole, were mainly visible on leaf petioles. Necrosis, blackening and deformation by bending down or twisting were extremely characteristic. In some cases the necrosis spread to blade base (Fig. 1). Such leaves fell down prematurely, in spring. From dead leaf petioles almost entirely one fungal species was isolated - Tubakia dryina. Sporadically also fungi representing the genera of Alternaria, Coniothyrium and Epicoccum were isolated.

Tubakia dryina colony on MEA was woolly to floccose, reaching after 21 days diameter of $86 \mathrm{~mm}$ (on average), whitish at first, then olive-grey (Fig. 2). On PDA the growth was slower (72 $\mathrm{mm}$ after 21 days, on average), the structure was more compact, with concentric rings more distinct cloudy, with deep bay-like cuts at the circumference (Fig. 3). Black sporodochia formed concentric rings on the colony surface and produced numerous conidia of two types. Macroconidia were 1-celled, hyaline to light olive-brown, elliptical, sometimes truncate at the basis, 12-15 x 7-8 $\mu \mathrm{m}$ (Fig. 4). Beside macroconidia also 1-celled hyaline, rod-shaped to oblong elliptical microconidia measuring 6-8 $22 \mu \mathrm{m}$ (Fig. 4) were formed.

Over a half of artificially inoculated leaves $(65.0 \%)$ and all inoculated shoots displayed disease symptoms after 4-8 weeks. Tissue along vein in the upper part of 
leaves was necrotic (Fig. 5), and some leaves died (Fig. 6). Wounds in the inoculated shoots did not heal, and the tissues around - particularly above wounds, were necrotic and discoloured brown-black (Fig. 7). In the leaves occurring there, leaf petiole was necrotized and black which resulted in dieback of entire leaves (Figs 7, 8). The necrotized leaves were not properly developed and displayed atrophy (Fig. 6). In the necrotic tissue $T$. dryina only sporadically produced conidiomata of pycnothyrium type.

Out of 210 samples of tissues from inoculated leaves and shoots which were necrotized, 59.6\% yielded microorganisms. Tubakia dryina was found in all plant parts in question (leaves, leaf petioles, shoots) and isolated from $28.6 \%$ of tissue samples. The following species were isolated beside $T$. dryina: Alternaria alternata (Fr.) Keissler (0.5\%), Apiognomonia quercina (5.7\%), Aureobasidium pullulans (de Bary) Arn. (3.8\%), Coniothyrium olivaceum Sacc. (2.4\%), Fusarium sp. (10.0\%), Hormonema sp. (1.0\%) and Lecytophora sp. (0.5\%). From $7.1 \%$ of tissue samples bacterial colonies were obtained, which displayed in vitro antagonistic effect on $T$. dryina colony. After 2 weeks of common growth (in two organism cultures) on MEA (inoculum distance $25 \mathrm{~mm}$ ), an inhibition zone was produced of 3-15 mm, and the $T$. dryina colony radius towards the bacterial colony was reduced 3-5 times (Fig. 9).

\section{DISCUSSION}

Tubakia dryina [syn. Actinopelte dryina (Sacc.) Hoehn.] occurs in North America, Europe and Asia, while its teleomorph, described as Dicarpella dryina Belisario, was described only in Italy (Holdenrieder, Kowalski 1989; Proffer 1990; Belisario 1991; Butin 1996; Kaneko, Kanek 2004). It is found mainly on oaks, and rarely on other plants of Acer, Castanea, Liquidambar, Photinia, Sasafras and Ulmus genera (Proffer 1990). It was described in Poland only once - by Przybył (1995). In plants the species is able to occur as endophyte, causing no disease symptoms (Body, Rayner 1984; Przybył 1995; Cohen 1999; Gennaro et al. 2003; Kaneko, Kaneko 2004). It is also being connected with disease symptoms on leaves and, rather seldom, on shoots (Holdenrieder, Kowalski 1989; Butin 1996). On Quercus spp. leaves the symptoms are circular, tan to dark reddish brown spots, 1-15 mm in diameter. Small spots may coalesce to form large irregular blotches (Hepting 1971; Munkvold, Neely 1990; Proffer 1990). On Castanea leaves brown necrotic spots reach up to $9 \mathrm{~mm}$ in diameter and the lesions are surrounded by a prominent chlorotic halo, up to $6 \mathrm{~mm}$ wide (El- G holl et al. 1996). Pathogenicity tests with $T$. dryina yielded inconsistent results. Artificial inoculation of $Q$. phillyraeoides, Q. glauca and Castanea pubinervis performed by Yokoy ma and Tubaki (1971) revealed no pathogenicity. The T. dryina isolate examined by Hold en rieder and Kow alski (1989) did not display any pathogenicity towards shoots and very low pathogenic potential on leaves of Q. robur. On the other hand, E1-Gholl et al. (1996), Kim and Wagner (1997), and Munkvold and Nelly (1990) confirmed pathogenicity of the species. The $T$. dryina isolate tested by the author proved also pathogenic. Despite the fact that it was not morphologically different from the isolates investigated by other authors (Yokoyama, Tubaki 1971; Holdenrieder, Kowalski 1989; Proffer 1990), it caused different type of symptoms on leaves - a very specific necrosis and blackening of leaf petioles, and necrosis of leaf blade 
- at first along veins and than of the entire leaf. The necrosis spread so quickly that the leaves did not grow to normal size. The symptoms, very different from those observed by other authors (Munkvold, Nelly 1990; Proffer 1990; El-Gholl et al. 1996), could have resulted from infection of very young developing leaves of $Q$. robur. That early artificial inoculation was aimed at finding out if $T$. dryina could cause necrosis together with malformation and blackening of leaf petioles, leading - according to the 1999 observations - to premature leaf dropping. The results confirmed the hypothesis, which is of interest as the symptoms described were never observed in connection with T. dryina infection. They also pointed to the possible effect of bacteria inhabiting $Q$. robur leaves on development of $T$. dryina.

Acknowledgements: The author thanks Mrs Mgr J. Michalik for help in laboratory work. These investiga tions were carried out under the project No.2 P06L 03626.

\section{REFERENCES}

Belisario A. 1991. Dicarpella dryina sp.nov., teleomorph of Tubakia dryina. Mycotaxon 41 (1): 147155.

Boddy L., Rayner A. D. M. 1984. Fungi inhabiting oak twigs before and at fall. Transactions of the British Mycological Society 82: 501505.

But in H. 1992. Effect of endophytic fungi from oak (Quercus robur L.) on mortality of leaf inhabiting gall insects. Eur. J. For. Path. 22: 237246.

But in H. 1996. . Krankheiten der Wald und Parkbaeume . Georg Thieme Verlag. Stuttgart.

Cohen S. D. 1999. Technique for large scale isolation of Discula umbrinella and other foliar endophytic fungi from Quercus species. Mycologia 91 (5): 917922.

El Gholl N. E., Schubert T. S., Pe a cock M. E. 1996. Tubakia Leaf Spot of Chestnut. Plant Pathol ogy Circular. 375: 13.

E11 is M. B., E11 is J. P. 1985. Microfungi on Land Plants. London, Sydney: Croom Helm.

Gennaro M., Gonthier P., Nicolotti G., 2003. Fungal Endophytic Communities in healthy and declining Quercus robur L. and Q. cerris L. trees in Northern Italy. J. Phytopathol. 151: 529534.

Gilman J. C., Wadley B. N., 1952, The ascigerous stage of Septoria querceti Thuem. Mycologia 44: 216220.

Hepting G. H. 1971. Diseases of forest and shade trees of the United States. USDA Forest Service. Agricultural Handbook No. 386. 658 pp.

Holdenrieder O., Kowalski T. 1989. Pycnidial formation and pathogenicity in Tubakia dryina. Mycol. Res. 92 (2): 166169.

Kan eko R., Kan eko S. 2004. The effect of bagging branches on levels of endophytic fungal infection in Japanese beech leaves. For. Path. 34: 6578.

Kim S. H., Wagne r V. M. 1977. Parasitism of Actinopelte dryina on oak leaves (Abstr.) Proceedings of American Phytopathological Society 4: 125126.

Kow a ls ki T., D u ra k E. 2000. Grzyby endofityczne IV. Mykobiota w żywych liściach Quercus robur oraz w nekrotycznych tkankach wokół wyrośli Andricus ostrea. Zesz. Nauk. AR Kraków 376: 2536.

Mańka K. 2005. Fitopatologia leśna. PWRiL. Warszawa.

Munkvold G. P., Neeley D. 1990. Pathogenicity of Tubakia dryina. Plant Disease 74: 518522.

Neely D., Himelick E. B. 1967. Characteristick and nomenclature of the oak antracnose fungus. Phytopathology 57: 12301236.

Proffer T. J. 1990. Tubakia leaf spot. Florida Department of Agriculture and Consumer Services, Divi sion of Plant Industry, Gainesville. Plant Pathology Circular No. 337. 2 p.

Przybył K. 1995. Zamieranie dębów w Polsce. Idee ekologiczne. Wyd. Sorus, Poznań, 8 (4): 185.

Sieber T., Hugentobler C. 1987. Endophytische Pilze in Blättern und Ästen gesunder und ge schädigter Buchen (Fagus sylvatica L.). Eur. J. For. Path. 17: 411425.

Yok oy a ma T., Tubaki K. 1971. Cultural and taxonomical studies on the genus Actinopelte. Research Communications, Institute for Fermentation, Osaka 5: 4377. 
Tubakia dryina - patogeniczność i symptomy na Quercus robur

Streszczenie

W pracy przedstawiono wyniki badań nad objawami chorobowymi obserwowanymi w 1999 r. w rejonie Opola u Quercus robur w postaci nekrozy, deformacji i czernienia ogon ka liściowego, co prowadziło do przedwczesnego opadu liści. Z martwych tkanek izolowano prawie wyłącznie kolonie jednego gatunku grzyba, który zidentyfikowano jako Tubakia dry ina. Gatunek ten wytwarzał in vitro zarówno makro jak i mikrokonidia, wykazując nieco szybszy wzrost na pożywce agarowomaltozowej niż na pożywce glukozowoziemniaczanej. Po przez sztuczną inokulację liści i pędów $Q$. robur wykazano patogeniczne właściwości bada nego szczepu T. dryina. Scharakteryzowano różne typy objawów chorobowych uzyskanych w trakcie tego eksperymentu. Zwrócono uwagę na ich odmienność w porównaniu z objawami obserwowanymi w innych krajach. 
